\title{
Book Review: The International Status of Education about the Holocaust - A Global Mapping of Textbooks and Curricula
}

\author{
Michael Polgar* \\ Penn State University, Hazleton, PA, United States
}

Keywords: holocaust, education, memory, survival, UNESCO

\author{
A Book Review on \\ The International Status of Education about the Holocaust - A Global Mapping of Textbooks \\ and Curricula
}

Peter Carrier, Eckhardt Fuchs and Torben Messinger, (Paris, France: UNESCO), 2015, 238 pages, ISBN: 9789231000331.

Summarizing a UNESCO study of Holocaust education around the world, this report provides information about global curricular perspectives on Holocaust education, including textbooks. The Georg Eckert Institute, with support from UNESCO and over 100 collaborating researchers, produced this analysis (Carrier et al., 2015). Insights show how varied historical concepts and narratives both converge and diverge, creating a fragmented but "cosmopolitan culture of memory" in Holocaust education (Olick and Levy, 1997; Levy and Sznaider, 2002, 2006).

This report can be used to recommend new policies and directives and to improve any Holocaust curricula. Findings show that Holocaust concepts and perspectives are common in European nations but, in parts of the global south, sometimes absent, muted, or distorted (Carrier et al., 2015). Mutual educational exchange can help improve Holocaust education, particularly for nations and groups that were historically uninvolved in the Holocaust. Results of this report become even more useful with a complementary UNESCO edition and its component essays (Fracapane and Hass, 2014).

While curricular content is absent in a few nations, and while some major nations provide educational resources on only contextual topics (like world war or the Nazis), many national curricular materials provide either direct reference to the Holocaust (Shoah, genocide against Jews) or partial reference (Holocaust as example of genocide and need for human rights law).

Holocaust education recognizes that genocide exemplifies clear and global moral standards for good and evil. This provides educators opportunities to articulate moral and legal standards to prevent and sanction injustices. Lessons from the Holocaust may be complicated by nationalistic (and sometimes even biased) heroic narratives. Evidence of tensions regarding nationalist bias is found in some materials from the Russian Federation and some former Soviet states (like Poland) (Carrier et al., 2015). Holocaust education serves many important uses in diverse nations, promoting communications about human rights, along with civic education toward positive national and international transformations (Fracapane and Hass, 2014; Stevick and Gross, 2014).

How representative and effective are global curricula, including texts? This report examines curricula and textbooks. Across 193 nations, 272 officially recognized curricula for students 14-18 years old were collected, analyzed, charted, and mapped. Complementary comparisons and assessments summarize 89 textbooks in 26 countries (Carrier et al., 2015). Research explores the "meta-historical" questions about if and how the Holocaust has been conceptualized as an 
antisemitic genocide or/and "universalized" as a model to represent other or all genocides, or even all atrocities. Such "universalization" is a processes that can, with some risk to historical focus and accuracy, generate cosmopolitan, less culturally focused forms of historic memory (Levy and Sznaider, 2002).

Report authors ask three questions to guide curricular analysis. First, about absolute status: Do curricula stipulate teaching about Holocaust? In what terms ("semantic status")? How does curriculum contextualize Holocaust in history? Textbook analyses provide national and international portraits. Global comparisons show that educational portraits in textbooks may not always reflect the status of the Holocaust in the wider media or in family stories. In many ways, the Holocaust is many narratives which raise universal questions about civic morality around the globe, as noted by many authors and comparative studies of textbooks (Alexander, 2009; Bromley and Russell, 2010; Pingel, 2014).

Findings show that many nations make direct reference to the Holocaust (or Shoah), while other nations use alternative terms (e.g., "the Jewish genocide"). Fewer nations make partial reference to the Holocaust, indirectly stipulating teaching about the Holocaust as an example (rather than a focal topic) within a broader historical topic or as a basis of the need for human rights education. Some nations present it only in context, noting many problems in terms like the injustices practiced by Nazis, stages of genocide, human rights violations, and antisemitism, but not specifically addressing the Holocaust as an event (Carrier et al., 2015).

In some nations, the report finds no or very limited reference to the Holocaust in curricula, even in the context of other topics. Even so, national curricula are in a state of transition, often toward more state support for direct Holocaust education, as we can see from early adopters of state-supported curricula like Israel in 1981 (Stevick and Gross, 2014) and the United Kingdom in 1990 (Pearce and Chapman, 2017), and with more recent changes in Brazil and (in 2010) Finland (Carrier et al., 2015).

This UNESCO report finds some nations and textbooks focus particularly on Jewish victims while others expand to address Roma cultures, people with disabilities, and other groups subject to human rights abuses. Terms for atrocities or genocides which imply national responsibility may be muted or limited (with the notable exception of Nazi Germany). Careful use of educational

\section{REFERENCES}

Alexander, J. C. (2009). Remembering the Holocaust: a debate. Oxford; New York, NY: Oxford University Press.

Bromley, P., and Russell, S. G. (2010). The Holocaust as history and human rights: a cross-national analysis of Holocaust education in social science textbooks, 1970-2008. Prospects 40, 153-173. doi: 10.1007/s11125-0109139-5

Carrier, P., Fuchs, E., and Messinger, T. (2015). The International Status of Education about the Holocaust - A Global Mapping of Textbooks and Curricula. Paris: UNESCO.

Fracapane, K., and Hass, M. (2014). Holocaust Education in a Global Context. Paris: United Nations Educational, Scientific and Cultural Organization (UNESCO). language (as recommended by the USHMM) is not simply a minor "correctness" concern (United States Holocaust Memorial Museum, 2018). Good concepts and word choices help national and other curricula to explore the topic without over-emphasis of events that could imply "self-incrimination." Holocaust education can address complexities of national exploitation by oppressive authoritarian military regimes, as we find in Poland, where Nazi policies (not Polish state authorities) assigned and designed death camps in "blood-lands" like Auschwitz that became "ground zero" for mass murders from 1942 to 1945 (Gebert, 2014; Snyder, 2015).

UNESCO authors conclude that a high proportion of OECD (European) nations, which provided detailed data, more often prescribe compulsory Holocaust education, as do Israel and the United Kingdom (Carrier et al., 2015). In contrast, nations in Africa and Asia, among other regions, provided fewer data resources, and these resources subsequently show more limited, partial, or indirect forms of Holocaust education within national educational curricula and textbooks. Thus, there is room for growth in many regions, nations, and curricular dimensions, and more extensive subsequent research efforts remain needed. There are reasons to remain both optimistic and critical; the field of Holocaust education is experiencing innovation and profound developmental transformations (Stevick and Gross, 2014). In this process, we do well to attend to and help guide the future of these important developments.

\section{AUTHOR CONTRIBUTIONS}

The sole author MP is responsible for the content of this work.

\section{FUNDING}

Thank you to Penn State University (Hazleton Campus) for research development support to explore topics in Holocaust education.

\section{ACKNOWLEDGMENTS}

The author thanks The Olga Lengyel Institute (TOLI.us) and the United States Holocaust Memorial and Museum (USHMM) (and their partner-organizations) for generous support through educator training in Holocaust studies.

Gebert, K. (2014). "Conflicting memories: poland and jewish perceptions of the Shoah," in Holocaust Education in a Global Context, eds K. Fracapane and M. Hass (Paris: United Nations Educational, Scientific and Cultural Organization), 28-39.

Levy, D., and Sznaider, N. (2002). Memory unbound: the Holocaust and the formation of cosmopolitan memory. Eur. J. Soc. Theory 5, 87-106. doi: 10.1177/13684310020050 01002

Levy, D., and Sznaider, N. (2006). The Holocaust and Memory in the Global Age. [English]. Philadelphia, PA: Temple University.

Olick, J. K., and Levy, D. (1997). Collective memory and cultural constraint: Holocaust myth and rationality in german politics. Am. Sociol. Rev. 62, 921-936. 
Pearce, A., and Chapman, A. (2017). Holocaust education 25 years on: challenges, issues, opportunities. Holocaust Stud. 23, 223-230. doi: 10.1080/17504902.2017.1296082

Pingel, F. (2014). "The Holocaust in textbooks: from a European to a Global Event," in Holocaust Education in a Global Context, eds K. Fracapane and M. Hass (Paris: United Nations Educational, Scientific and Cultural Organization), 77-86.

Snyder, T. (2015). Black Earth: The Holocaust as History and Warning. 1st Edn. New York, NY: Tim Duggan Books.

Stevick, D., and Gross, Z. (2014). "Research in holocaust education: emerging themes," in Holocaust Education in a Global Context, eds K. Fracapane and M. Hass (Paris: United Nations Educational, Scientific and Cultural Organization), 59-76.
United States Holocaust Memorial Museum (2018). Teaching About the Holocaust: Resources for Educators. United States Holocaust Memorial Museum. Available online at: http://www.ushmm.org/educators.

Conflict of Interest Statement: The author declares that the research was conducted in the absence of any commercial or financial relationships that could be construed as a potential conflict of interest.

Copyright (C) 2018 Polgar. This is an open-access article distributed under the terms of the Creative Commons Attribution License (CC BY). The use, distribution or reproduction in other forums is permitted, provided the original author(s) and the copyright owner(s) are credited and that the original publication in this journal is cited, in accordance with accepted academic practice. No use, distribution or reproduction is permitted which does not comply with these terms. 